\title{
BIOLEACHING OF KAOLIN WITH Bacillus cereus: EFFECTS OF BACTERIA SOURCE AND CONCENTRATION ON IRON REMOVAL
}

\author{
YAP HAO JUN ${ }^{1}$, YONG SHIH NEE ${ }^{2}$, CHEAH WAN QI², SYLVIA CHIENG ${ }^{2}$ AND KUAN SENG \\ HOW*1
}

${ }^{1}$ Department of Mechanical and Material Engineering, Lee Kong Chian Faculty of Engineering and Science, Universiti Tunku Abdul Rahman, 43000 Kajang, Selangor. ${ }^{2}$ Centre for Biotechnology and Functional Food, Faculty of Science and Technology, Universiti Kebangsaan Malaysia, 43600, Bangi, Selangor.

*Corresponding author: kuansh@utar.edu.my

Submitted: 30 August 2019 Accepted: 12 December 2019

http://doi.org/10.46754/jssm.2020.06.009

\begin{abstract}
The presence of iron impurities in kaolin can negatively affect its whiteness index and refractory properties. Bacteria of the Bacillus species have been found to be effective in removing ferric ions [Fe(III)] from kaolin. This work examines the bioleaching of Fe (III) from kaolin using B. cereus. Two strains were tested: the first procured from an external laboratory and the second isolated from a kaolin sample. Bioleaching experiments were conducted at $30^{\circ} \mathrm{C}$ for five days. Changes in surface morphology of the kaolin were investigated using scanning electron microscopy, while chemical composition was analysed using energy dispersion X-ray spectroscopy. Dissolved Fe (II) concentration in kaolin leachates was measured spectrophotometrically using the phenanthroline method. Evident changes in the surface morphology of kaolin samples were observed in the presence of bacteria. Results also revealed higher Fe removal by indigenous $B$. cereus strain UKMTAR-4 isolated from kaolin (53.9\%) compared to B. cereus procured externally $(33.9 \%)$. When concentration of bacteria was progressively increased and bioleaching time extended to 10 days, presence of dissolved Fe (II) increased, indicating augmented bioleaching activity with increase of bacteria count.
\end{abstract}

Keywords: Sustainability, bioleaching, kaolin, iron, Bacillus cereus.

\section{Introduction}

The kaolinite group is considered as one of the four major groups of clay minerals with a chemical formula of $\mathrm{Al}_{2} \mathrm{Si}_{2} \mathrm{O}_{5}(\mathrm{OH})_{4}$. Structurally, kaolinite is comprised of silicate sheets $\left(\mathrm{Si}_{2} \mathrm{O}_{5}\right)$ bonded to aluminium oxide/hydroxide layers $\left(\mathrm{Al}_{2}(\mathrm{OH})_{4}\right)$, also known as gibbsite layers. Pure kaolinite $\left(\mathrm{Al}_{2} \mathrm{O}_{3} \cdot 2 \mathrm{SiO}_{2} \cdot 2 \mathrm{H}_{2} \mathrm{O}\right)$ appears white, but typical impurities such as quartz, iron oxides, mica, feldspar, titano-ferrous minerals, and organic matter are usually present (Abdel-Khalek et al. 2014). Kaolin is used to make ceramic as well as coating and filler pigment for paper, as filler for paint, rubber, plastics, fertilizers, food additive, medicine, and cosmetics. Purification of kaolin through conventional processing (such as grinding and magnetic separation) can remove majority of the impurities. However, these methods fall short of removing fine particles associated with colouring impurities, such as iron oxide and titanium oxide, that reduce their whiteness and brightness. Also, the application of conventional leaching technique to treat these fine colouring impurities is energy and cost intensive. The most promising new approach to remove these colouring materials sustainably is through biotechnological methods.

Biotechnological treatment of non-metals like silicates, carbonates and oxides is based on bacterial leaching of raw material and dissolution of ferum (Fe) ions (Štyriaková et al., 2007a). Bacterial dissolution ability is dependent on physico-chemical factors, such as temperature, $\mathrm{pH}$, redox potential, and presence of organic sources. Non-metallic raw materials contain no food source for microorganisms to utilize. Such materials may be leached by using heterotrophic bacteria or fungi, which necessitates the addition of organic carbon sources as energy for growth. So far, most experimental work carried out on clay-bacteria interactions were those concerning reduction of ferric [Fe (III)] to ferrous [Fe(II)] 
ions within the clay mineral structure by bacteria (Mueller, 2015).

The ability of bacteria to reduce Fe (III) in ferrous oxides was first observed by Starkey and Halvorson (1927). It was later noted by Bromfield (1954) that metabolic enzymes may enhance Fe reduction as mobilizers of Fe (III) oxides to $\mathrm{Fe}$ (II). It was not until Stucki \& Getty (1986) that the ability of bacteria to modify structural Fe in phyllosilicate clay minerals was observed. It was found that structural $\mathrm{Fe}$ (III) in clay minerals could be converted to $\mathrm{Fe}$ (II) under stimulation with bacterial growth. The authors measured $\mathrm{Fe}$ reduction in nutrient broth dispersions of ferruginous smectite inoculated with pure cultures of four Bacillus strains and discovered that high levels of Fe (II) (up to 20 $\%$ of total $\mathrm{Fe}$ ) were produced in each culture. The reduction of structural $\mathrm{Fe}$ in ferruginous smectites by a mixture of five Pseudomonas species was later investigated by Gates et al. (1993), and they found that a mixture of these bacteria yielded higher efficiency as a reductant than any of the species acting individually. Kostka et al. (1996) used a pure culture of Shewanella putrefaciens (strain MR-1) and found that at $\mathrm{pH} 5$ to 6 and temperatures of $25^{\circ} \mathrm{C}$ to $37^{\circ} \mathrm{C}$, the MR-1 strain of $S$. putrefaciens rapidly reduced $\mathrm{Fe}(\mathrm{III})$ in smectite up to $15 \%$ in four hours compared to several days with Pseudomonas.

Štyriaková and Styriak (2000) found that up to $43 \%$ of Fe (III) could be removed from kaolin using B. cereus after one month of bioleaching. Guo et al. (2010) studied the effect of carbon and nitrogen sources on the removal of Fe impurities from kaolin using a mixed culture of $B$. cereus, B. sphaericus and B. mycoides. They found that up to $50 \%$ of $\mathrm{Fe}$ impurities were removed, and up to $82 \%$ of whiteness index may be achieved with bioleaching. He et al. (2011) examined the effects of organic acids, complexing agents and heavy metals on the bioleaching of Fe from kaolin using a mixed culture of $B$. cereus, $B$. sphaericus and $B$. mycoides, and found that adding oxalic acid to the leaching solution would enhance the leaching of Fe. Zegeye et al. (2013) used the Shewanella genus ( $S$. oneidensis, S. algae and S. putrefaciens, respectively) to remove Fe from kaolin, and found improvements in kaolin brightness up to $79 \%$ with a whiteness index up to $66 \%$ within five days of bioleaching at $30{ }^{\circ} \mathrm{C}$. They also varied the cell to kaolin ratio and found that the brightness and whiteness increased with increasing cell concentration to a peak and then decreased. The optimum kaolin to cell ratio was between $2.5 \times 10^{5}$ to $6.2 \times 10^{5}$ cfu/g kaolin. Liu et al. (2017) reduced iron in clay minerals using $S$. oneidensis and found that humic acid in environmental concentrations could enhance reduction of $\mathrm{Fe}$ (III) in clay minerals through electron transfer enhancement and $\mathrm{Fe}$ (II) complexation.

As shown by literature, bacteria such as Shewanella, Bacillus and Pseudomonas species have been found to be reasonably effective in removing Fe from kaolin (Stucki \& Getty, 1986; Styriakova et al., 2000; Styriakova et al., 2007; He et al., 2011). While, most results established a noticeable effect of the bacteria on the redox state of structural $\mathrm{Fe}$, questions persist relating to the effects of bacteria source and bacteria concentration on the $\mathrm{Fe}$ reduction rates.

This work is aimed at evaluating the iron reduction rates of kaolin by two different strains of $B$. cereus - commercially available $B$. cereus and indigenous $B$. cereus strain UKMTAR-4 isolated from a kaolin sample. Kaolin samples before and after bioleaching are analysed using scanning electron microscopy (SEM) for changes in surface morphology and energy dispersion X-ray spectroscopy (EDX) for changes in chemical composition. Changes in dissolved $\mathrm{Fe}$ (II) concentration are measured spectrophotometrically using the phenanthroline method for extended bioleaching experiments.

\section{Materials and Methods}

\section{Mineral Preparation}

The kaolin samples were obtained from a mine in Bidor, Perak, owned by Kaolin Malaysia. The samples were procured after filtration, but before any heating process that turned it into specific grades. The chemical composition of the kaolin 
was $50 \% \mathrm{SiO}_{2}$ and $36 \% \mathrm{Al}_{2} \mathrm{O}_{3}$. The average particle size was between 2.5 to $3.5 \mu \mathrm{m}$. The samples were rolled, crushed, mixed, and stored. Representative samples were analysed using a Hitachi S-3400N scanning electron microscope (Hitachi Hi-Tech Solutions, Fukuoka, Japan) and energy dispersion X-ray spectroscope.

\section{Isolation of Bacteria}

Isolation of bacteria from a kaolin sample was conducted using dilution and plating method. One gram of kaolin was added to 10 $\mathrm{mL}$ of distilled water and mixed to obtain a homogeneous suspension. Ten-fold serial dilution was performed by removing $1 \mathrm{~mL}$ of suspension and transferring it to $9 \mathrm{~mL}$ of distilled water. The suspensions were then vortexed and $0.1 \mathrm{~mL}$ from each dilution was spread on Luria Bertani (LB) agar plates before being incubated at $37^{\circ} \mathrm{C}$ for 24 hours. After incubation, colonies formed on the agar plates were examined. Individual bacterial colonies were selected and grown on fresh LB agar plates to obtain a pure culture. For long term-storage, stock cultures were preserved in LB broth and $30 \%$ glycerol at $-80^{\circ} \mathrm{C}$.

\section{Identification of Bacteria Isolates}

Bacteria isolated from the kaolin sample were identified and characterized through Gram staining and polymerase chain reaction (PCR) of the conserved region of bacterial 16S rRNA. Bacterial DNA was extracted from single colonies of bacterial strains from the pure culture plates. The colonies were suspended in $40 \mu \mathrm{L}$ of $\mathrm{ddH}_{2} \mathrm{O}$ and boiled at $95^{\circ} \mathrm{C}$ for 10 $\mathrm{min}$. The cell suspension was then centrifuged at $14,000 \mathrm{rpm}$ for one minute and the supernatant was used as the PCR template. Amplification of bacterial 16S rRNA genes were carried out using universal 27F forward (5'-AGAGTTTGATCMT GGCTCAG-3') and 1492R reverse (5'-TACGG YTACCTTGTTACGACTT-3') primers.

PCR was performed using the Toyobo KOD-Plus-Neo kit (Toyobo Biotech, Osaka, Japan) under the following conditions: an initial denaturation step at $94^{\circ} \mathrm{C}$ for $2 \mathrm{~min}$, followed by 30 cycles of denaturation at $98^{\circ} \mathrm{C}$ for $10 \mathrm{~s}$, annealing at $48^{\circ} \mathrm{C}$ for $30 \mathrm{~s}$ and extension at $68^{\circ} \mathrm{C}$ for $2 \mathrm{~min}$, before the final extension at $68^{\circ} \mathrm{C}$ for $10 \mathrm{~min}$.

The PCR products were verified through agarose gel electrophoresis and purified using the MinElute Gel Extraction Kit (Qiagen, Hilden, Germany) according to the manufacturer's protocol. Purified PCR products were subjected to DNA sequencing and the results were compared and verified with sequences in the National Institutes of Health's GenBank database using BLAST (https://blast.ncbi.nlm. nih.gov) to determine sequence homology. Sequence alignment for strain UKMTAR-4 and 21 selected Bacillus spp. was performed using CLUSTAL W software. All positions containing gaps and missing data were eliminated prior to phylogenetic tree construction. Evolutionary analyses were conducted in MEGA X using Neighbour-Joining method with 1,000 bootstrap replicates (Kumar et al., 2018).

\section{Preparation of Inoculum}

A single colony of strain UKMTAR-4 was selected and inoculated into $10 \mathrm{~mL}$ LB broth and incubated at $37{ }^{\circ} \mathrm{C}$ on a shaker $(250 \mathrm{rpm})$ overnight, before being used as inoculum for bioleaching experiments. Cell density of the overnight culture was measured using a cell densitometer at an absorbance wavelength of 600 $\mathrm{nm}$ (Amersham Biosciences, Buckinghamshire, United Kingdom).

\section{Bioleaching Experiments}

Prior to bioleaching experiments, $10 \mathrm{~g}$ of kaolin was added into $250 \mathrm{~mL}$ Erlenmeyer flasks and autoclaved at $121^{\circ} \mathrm{C}$ for $20 \mathrm{~min}$. A total of $80 \mathrm{~mL}$ of filtered-sterile glucose solution $(10 \mathrm{~g} / \mathrm{L})$ were added into the flasks containing kaolin under aseptic conditions. The bacterial overnight culture was then inoculated into the flasks to achieve final concentration of $2.4 \times$ $10^{8} \mathrm{cfu}$. The flasks were then mounted on the incubator-shaker for five days at $30^{\circ} \mathrm{C}$ and 250 rpm. After the bioleaching experiments, the filtered solids were dried at $80^{\circ} \mathrm{C}$ for $24 \mathrm{~h}$, and 
a portion was sent for SEM and EDX analyses. The commercial B. cereus (obtained from UKM Culture Collection Centre in Bangi, Selangor) and the isolated strain UKMTAR-4 were tested in separate experiments together with a control sample. Equation (1) was used to compute the Fe (III) removal rate using the initial and final weight percentages obtained from EDX analysis.

$$
\text { Fe (III) removal rate (\%) }=\left|\frac{X_{i}-X_{f}}{X_{i}}\right| \times 100 \%
$$

where;

$$
\begin{aligned}
& X_{i}=\text { initial weight percentage (wt \%) } \\
& X_{f}=\text { final weight percentage (wt \%) }
\end{aligned}
$$

\section{Extended Bioleaching Experiments}

To evaluate the effect of bacteria concentration on iron removal, bioleaching experiments were conducted at bacteria concentrations of $3 \times 10^{8}$ cfu, $6 \times 10^{8} \mathrm{cfu}$ and $9 \times 10^{8} \mathrm{cfu}$. The experiments were conducted for 10 days using strain UKMTAR-4, and samples were taken at twoday intervals to measure the dissolved Fe (II) concentration. Dissolved Fe (II) concentrations were measured using the phenanthroline method as described by Herrera et al. (1989).

\section{Results and Discussion}

\section{Molecular Identification of UKMTAR-4}

A total of six distinct bacteria strains were successfully isolated and purified from the kaolin sample. Through the amplification of the 16S rRNA partial sequence using the universal primers $27 \mathrm{~F}$ and $1492 \mathrm{R}$, amplicons within the size range of 1000-1500 bp were obtained and sequenced. Analysis of these sequences through BLASTn revealed that the Bacillus species predominated in kaolin under aerobic conditions. Similar observation was also reported by Guo et al. (2010), where three Bacillus strains were identified in the sludge sample from a kaolin processing plant. Using the 16S rRNA partial sequence analysis, strain UKMTAR-4 demonstrated high homology to Bacillus spp. $(>99 \%)$. Based on the phylogenetic tree constructed with 21 sequences from different Bacillus spp., it was found that the UKMTAR-4 strain showed high similarity and was clustered together with other Bacillus cereus strains (Figure 1). Therefore, strain UKMTAR-4 was most probably a $B$. cereus and would henceforth be referred as $B$. cereus strain UKMTAR-4. This strain was selected for subsequent bioleaching experiments as previous studies had reported the ability of $B$. cereus to effectively remove iron from non-metallic minerals, such as feldspar, quartz, and kaolin (Štyriaková et al., 2007b; Roy et al., 2010).

\section{Comparative Bioleaching Efficiency}

The EDX results revealed a notable decrease in the amount of $\mathrm{Fe}$ impurities in treated kaolin. The weight percentage of $\mathrm{Fe}$ in the kaolin sample was $1.23 \%$ before bioleaching, and it decreased to $0.81 \%$ for those in contact with $B$. cereus and $0.61 \%$ for those in contact with $B$. cereus strain UKMTAR-4 (Table 1). Similarly, the atomic percentage of $\mathrm{Fe}$ decreased from $0.47 \%$ to $0.30 \%$ for kaolin in contact with $B$. cereus, and to $0.22 \%$ in contact with $B$. cereus strain UKMTAR-4 (Table 2). Fe removal rates were also computed and for the kaolin sample in contact with B. cereus strain UKMTAR-4, the rates were higher than those of the kaolin in contact with $B$. cereus $(53.9 \%$ vs $33.9 \%$ ). The rates indicated that $B$. cereus strain UKMTAR-4 isolated from kaolin was able to reduce higher amounts of $\mathrm{Fe}$ (III) than B. cereus procured externally. The rates were comparable to the results from previous bioleaching work testing B. cereus with kaolin (Štyriaková \& Štyriak, 2000; Guo et al., 2010), which yielded 50 to 53 $\%$. A study on Bacillus species with feldspar and quartz samples both yielded $60 \%$ of Fe removal (Štyriaková et al., 2007a; 2007b). The slight difference in Fe content in the control sample compared to untreated kaolin was attributed to assay variations in the kaolin samples. 


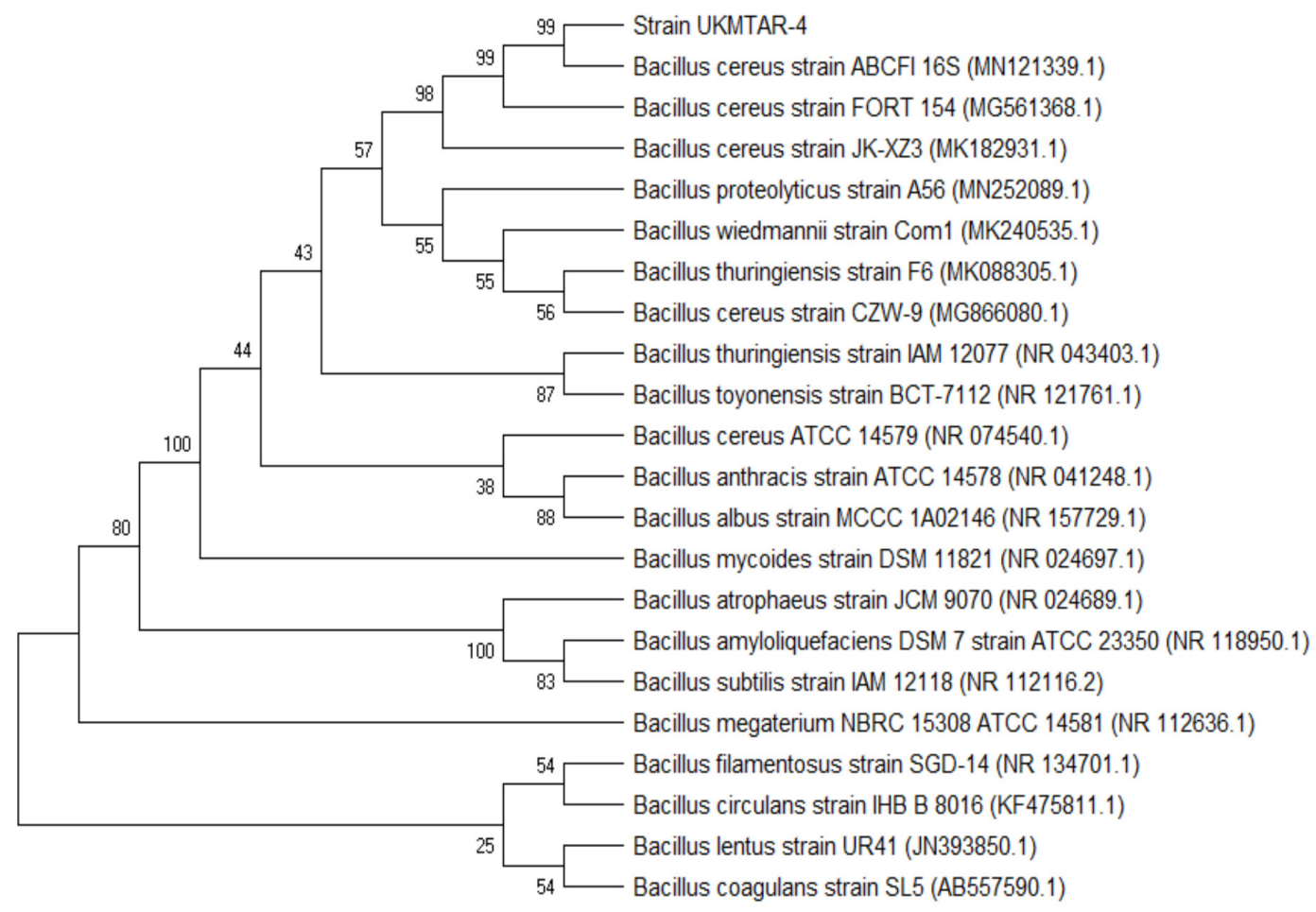

Figure 1: Phylogenetic analysis of strain UKMTAR-4 inferred using neighbour-joining method. Bootstrap values based on 1,000 replications are shown next to the branches as percentages

Table 1: Chemical composition of kaolin before and after bioleaching with B. cereus (in weight \%)

\begin{tabular}{lcccc}
\hline & \multicolumn{4}{c}{ Weight percentage (wt \%) } \\
\cline { 2 - 5 } Elements & Untreated & Control Sample & B. cereus & $\begin{array}{c}\text { B. cereus strain } \\
\text { UKMTAR-4 }\end{array}$ \\
\hline $\mathrm{O}$ & 43.6 & 46.9 & 48.1 & 48.5 \\
$\mathrm{Mg}$ & 1.25 & 1.31 & 1.25 & 1.22 \\
$\mathrm{Al}$ & 21.9 & 20.6 & 20.4 & 20.7 \\
$\mathrm{Si}$ & 28.0 & 26.4 & 26.2 & 25.6 \\
$\mathrm{~K}$ & 4.08 & 3.58 & 3.30 & 3.41 \\
$\mathrm{Fe}$ & 1.23 & 1.32 & 0.81 & 0.61 \\
\hline Standard & 1.15 & 1.06 & 0.96 & 0.69 \\
error (\%) & & & 33.9 & 53.9 \\
\hline Fe (III) removal rate (\%) & &
\end{tabular}


Table 2: Chemical composition of kaolin before and after bioleaching with $B$. cereus strain UKMTAR-4 (in atomic \%)

\begin{tabular}{lcccc}
\hline & \multicolumn{3}{c}{ Atomic percentage (at \%) } \\
\cline { 2 - 5 } Elements & Untreated & Control Sample & B. cereus & $\begin{array}{c}\text { B. cereus } \text { strain } \\
\text { UKMTAR-4 }\end{array}$ \\
\hline $\mathrm{O}$ & 57.8 & 61.0 & 62.0 & 62.4 \\
$\mathrm{Mg}$ & 1.09 & 1.12 & 1.06 & 1.03 \\
$\mathrm{Al}$ & 17.3 & 15.9 & 15.6 & 15.8 \\
$\mathrm{Si}$ & 21.2 & 19.6 & 19.3 & 18.8 \\
$\mathrm{~K}$ & 2.22 & 1.91 & 1.75 & 1.80 \\
$\mathrm{Fe}$ & 0.47 & 0.49 & 0.30 & 0.22 \\
\hline Standard error (\%) & 1.09 & 1.00 & 0.87 & 0.60 \\
\hline Fe (III) removal rate (\%) & & & 35.4 & 54.5 \\
\hline
\end{tabular}

Figure 2a shows the surface morphology of untreated kaolin. The image showed kaolinite present in the form of well-shaped crystals with different sizes and thickness. Some sites were observed to have relatively round and smooth edges. The image was compared to three other samples, namely control (Figure 2b), kaolin in contact with B. cereus (Figure 2c) and kaolin in contact with $B$. cereus strain UKMTAR-4 (Figure 2d). For the control sample, the kaolin surface appeared similar to the untreated sample
(Figure 2b). For kaolin that has come into contact with the bacteria, the particles appeared damaged and slightly broken (Figure 2c \& 2d), indicating microbial action during bioleaching. The images also revealed what seemed to be a transition of the kaolin surface from a more amorphous structure before contact with bacteria, to a more crystalline structure after contact. No secondary minerals were presumed formed due to the bioleaching time of five days.
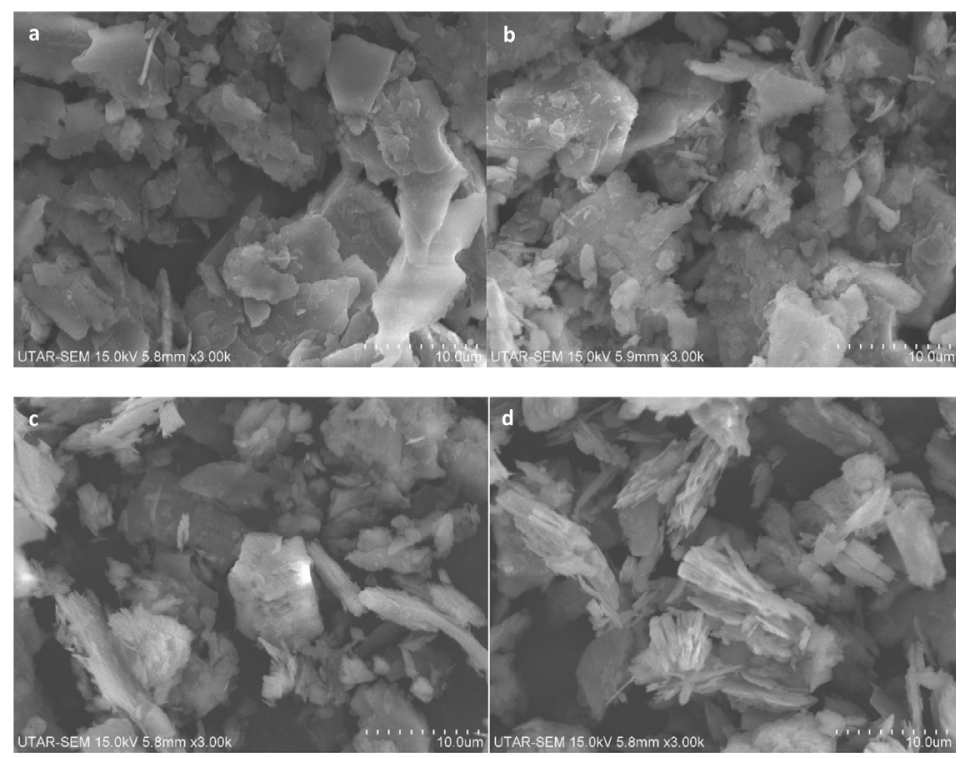

Figure 2: a) SEM image of the untreated kaolin. b) SEM image of kaolin after experiment without bacteria (control sample). c) SEM image of kaolin after bioleaching with B. cereus. d) SEM image of kaolin after bioleaching with $B$. cereus strain UKMTAR-4 


\section{Effects of Bacterial on Bioleaching Efficiency}

Bioleaching experiments were carried out for 10 days using $B$. cereus strain UKMTAR-4, and samples were taken at two-day intervals for dissolved Fe (II) concentration measurement. Figure 3 shows that for every $3 \times 10^{8} \mathrm{cfu}$ of bacteria, the $\mathrm{Fe}$ (II) concentration would increase linearly in the solution until it peaked on the eighth day with a value of $1.91 \mathrm{mg} / \mathrm{L}$, before reducing slightly on the 10 th day to $1.35 \mathrm{mg} / \mathrm{L}$. Similar trends were observed when bacteria concentrations were increased to $6 \times 10^{8}$ and $9 \times 10^{8} \mathrm{cfu}$, with slight fluctuations in value. Maximum Fe (II) dissolution of $2.26 \mathrm{mg} / \mathrm{L}$ was achieved with $9 \times 10^{8} \mathrm{cfu}$ bacteria after eight days. The reduction in $\mathrm{Fe}(\mathrm{II})$ concentration from Day 4 to Day 6, and Day 8 to Day 10, could be possibly due to a combination of factors like, among others, nutrient depletion as the bacteria consumed the glucose for growth as well as changes in redox potential of the solution leading to Fe precipitation.

Fe precipitation was speculated to have occurred in Štyriaková et al. (2007a), where Bacillus species was used in the bioleaching of feldspar, and a similar reduction in $\mathrm{Fe}$ (II) concentration was observed. Further work would have to be conducted to confirm the speculation by measuring the bacteria growth curve and solution redox potential throughout the bioleaching period.

As the bacteria concentration incrementally increased in solutions from $3 \times 10^{8}$ cfu to $9 \times$ $10^{8} \mathrm{cfu}$, the amount of Fe (II) dissolved was also observed to increase. The trend indicated augmented bacterial leaching activity with increase in bacteria count, where the Fe (III) in kaolin was reduced progressively by the bacteria to $\mathrm{Fe}$ (II) in the solution. The trend coincided with that of Zegeye et al. (2013), where Shewanella bacteria was used in the bioleaching of kaolin, and it increased the treated samples' brightness and whiteness index with higher bacteria concentrations of up to $5 \times 10^{5} \mathrm{cfu} / \mathrm{g}$ kaolin $/ \mathrm{mL}$ medium. The brightness and whiteness index were an indication of bacterial leaching activity, indicating that less Fe impurities were present in kaolin when brightness and whiteness indexes were higher.

\section{Conclusion}

The Fe (III) oxide impurities present in kaolin could be reduced by $B$. cereus. SEM images showed morphological changes on the surface of the kaolin after contact with two strains of the

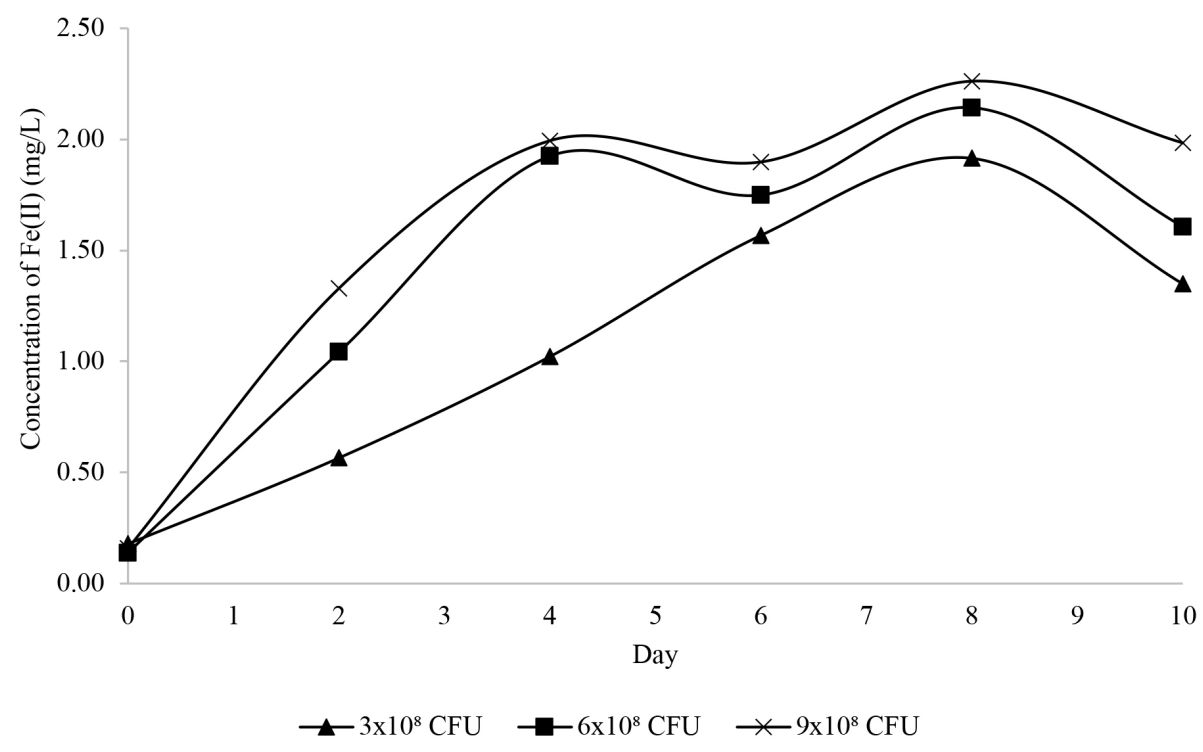

Figure 3: Effects of various bacterial concentrations on dissolution of Fe in kaolin 
bacteria. After five days of incubation at $30^{\circ} \mathrm{C}$, the highest $\mathrm{Fe}$ (III) removal rate was 53.9 weight percentage by $B$. cereus strain UKMTAR-4 compared to 33.9 weight percentage by $B$. cereus. The difference indicated that indigenous $B$. cereus had greater ability to reduce the Fe (III) in kaolin than the $B$. cereus procured externally. As the bacteria concentration increased incrementally from $3 \times 10^{8} \mathrm{cfu}$ to $9 \times 10^{8} \mathrm{cfu}$, the amount of $\mathrm{Fe}$ (II) in the solution also increased progressively, indicating augmented bacterial leaching activity with increase in bacteria count.

\section{Acknowledgements}

The authors wish to thank Professor Sheila Nathan of the Molecular Biology Laboratory in Universiti Kebangsaan Malaysia and Dr Gobi Vetharatnam of the Laboratory Management and Safety Administration in Universiti Tunku Abdul Rahman for access to lab facilities. Special thanks also to Kaolin Malaysia Sdn Bhd for providing the samples.

\section{References}

Abdel-Khalek, N., Seiem, K., Mohammed, S., ElHendawy, H., \& Elbaz, R. (2014). Interaction between kaolinite and Staphylococcus gallinarum bacteria. Journal of Mining World Express, 3, 46-52.

Bromfield, S. (1954). Reduction of ferric compounds by soil bacteria. Journal of General Microbiology, 11(1),1-6.

Gates, W., Wilkinson, H., \& Stucki, J. (1993). Swelling properties of microbially reduced ferruginous smectite. Clays and Clay Minerals, 41(3), 360-364.

Guo, M., Lin, Y., Xu, X., \& Chen, Z. (2010). Bioleaching of iron from kaolin using $\mathrm{Fe}$ (III)-reducing bacteria with various carbon nitrogen sources. Applied Clay Science, 48(3), 379-383.

He, Q., Huang, X., \& Chen, Z. (2011). Influence of organic acids, complexing agents and heavy metals on the bioleaching of iron from kaolin using $\mathrm{Fe}$ (III)-reducing bacteria. Applied Clay Science, 51(4), 478483.

Herrera, L., Ruiz, P., Aguillon, J., \& Fehrmann, A. (1989). A new spectrophotometric method for the determination of ferrous iron in the presence of ferric iron. Journal of Chemical Technology \& Biotechnology, 44(3), 171181.

Kostka, J., Stucki, J., Nealson, K., \& Wu, J. (1996). Reduction of structural Fe (III) in smectite by a pure culture of Shewanella putrefaciens strain MR-1. Clays and Clay Minerals, 44(4), 522-529.

Kumar, S., Stecher, G., Li, M., Knyaz, C., \& Tamura, K. (2018). MEGA X: Molecular evolutionary genetics analysis across computing platforms. Molecular Biology and Evolution, 35(6), 1547-1549.

Liu, G., Qiu, S., Liu, B., Pu, Y., Gao, Z., \& Wang, J. (2017). Microbial reduction of Fe (III)-bearing clay minerals in the presence of humic acids. Scientific Reports, 7(1), 1-9. doi: 10.1038/srep45354.

Mueller, B. (2015). Experimental interactions between clay minerals and bacteria: A review. Pedosphere, 25(6), 799-810. doi: 10.1016/s1002-0160(15)30061-8.

Roy, A., Singh, S., Banerjee, P., Dana, K., \& Das Kumar, S. (2010). Bio-beneficiation of kaolin and feldspar and its effect on fired characteristics of triaxial porcelain. Bulletin of Materials Science, 33(3), 333-338.

Starkey, R., \& Halvorson, H. (1927). Studies on the transformations of iron in nature. II. Concerning the importance of microorganisms in the solution and precipitation of iron. Soil Science, 24(6), 381-402.

Stucki, J., \& Getty, P. (1986). Microbial reduction of iron in nontronite. Annual Meeting of the Soil Science Society of America Soil Science Society of America. (p. 279).

Štyriaková, I. \& Styriak, I. (2000). Iron removal from kaolins by bacterial leaching. Ceramics - Silikaty, 44, 135-141. 
Štyriaková, I., Styriak, I., \& Malachovský, P. (2007a). Nutrients enhancing the bacterial iron dissolution in the processing of feldspar raw materials. Ceramics - Silikaty, 51, 202-209.

Štyriaková, I., Štyriak, I., Malachovský, P., Večera, Z., \& Koloušek, D. (2007b). Bacterial clay release and iron dissolution during the quality improvement of quartz sands. Hydrometallurgy, 89(1-2), 99-106.

Zegeye, A., Yahaya, S., Fialips, C., White, M., Gray, N., \& Manning, D. (2013). Refinement of industrial kaolin by microbial removal of iron-bearing impurities. Applied Clay Science, 86, 47-53. 